\title{
IMPACT OF SOIL DRAINAGE TO THE RADIAL STEM GROWTH OF NORWAY SPRUCE (PICEA ABIES L. KARST.) IN PEATLAND FORESTS
}

\author{
Barbora Klempírová, Lukáš Dragoun, Róbert MarušÁK \\ Czech University of Life Sciences Prague, Faculty of Forestry and Wood Sciences, Kamýcká 129, \\ CZ-165 21 Praha 6-Suchdol
}

Klempířová, B., Dragoun, L., Marušák, R., 2013: Impact of soil drainage to the radial stem growth of Norway spruce (Picea abies L. Karst.) in peatland forests. Lesnícky časopis - Forestry Journal, 59(4): 241-247, 2013, 3 fig., tab. 3, ref. 376, ISSN 0323 - 1046. Original paper.

Peatland Norway spruce (Picea abies L. Karst.) forests represent very valuable ecosystems with considerable importance for nature conservation. However, a lot of peatland forests have been drained or used for opencast mining of peat. Since dendrochronological and dendroecological studies on trees growing on peatlands in Europe are not many, this study aimed to reconstruct the impact of drainage to the growth of trees in forest stands older than 100 years in the moment of drainage. Dendrochronological analysis was performed on two 0.25 -ha square sampling plots $(50 * 50 \mathrm{~m})$ in two pre-selected stands (control site vs. drained site) with similar natural conditions and age. The mean-value functions of the ring indices, comparing the drained site with the control site, in the period after 1940 revealed very similar radial-growth trends. After the year 1992, when one site was substantially drained, the radial-growth trends not showed any significant change. Likewise, the result of the independent two sample t-test for the period after 1992 has not revealed any substantial statistically important difference in the mean index between the control site and the drained site.

Keywords: Norway spruce; dendrochronology; tree-ring width; peatland; soil drainage; nature conservation

\section{Introduction}

In Central Europe's mountainous region, peatland Norway spruce (Picea abies L. Karst.) forests represent very valuable ecosystems with considerable importance for nature conservation. In spite of their location in the area of severe climatic conditions at upper climatic tree distribution limit, some of these forests have been significantly influenced with human use with aim to increase their timber production. A lot of peatland forests have been drained or used for opencast mining of peat.

Drainage as a mean of improving tree growth has been used extensively with positive results namely in Fennoscandinavia (PAaVILAINEN, PärVÄNEn, 1995), thus much of the international knowledge about improved forest growth on peatlands after drainage is based on results from the Nordic countries and Russia (Gustavsen et al., 1998). Drainage aerates part of the peat, resulting in a faster decomposition rate, which enables increased nutrient mineralization, which favour the tree growth (MoILANEN et al., 2012). Likewise, drainage might increase stand stability and stimulate radial stem growth, since water-logging in the soils cause worsened anchoring of trees due to higher occurrence of root decay and low cohesion between the soil particles and root surface (RotTMANN, 1989).

However, at the same time, forest drainage has negative effect on original ecosystems. Drainage lowers the water table, increase soil temperature (LIEFFERS, RothweLL, 1987), change water quality and increase $\mathrm{pH}$ soil values (PRÉvOST et al., 1999). Increased frequency and quantity of runoff peaks increases erosion and suspended sediment transport from treated areas (Martilla, Klove, 2010; Marttila et al., 2010). Hydrological study on effect of drainage suggested that the highest peak flows could be increased by drainage in cases of intensive rainstorms in catchments with already high (close to the soil surface) groundwater level (Iritz et al., 1994). 
Wetlands are known to be very sensitive to disturbance and the environmental impacts of management practices on wetlands must be considered before forest drainage becomes widespread (Prévost et al., 1999). In order to preserve these unique ecosystems, many of the remaining peatlands are protected on the national level or as NATURA 2000 site (ecological network of protected areas in the territory of the European Union).

The area of the Ore Mountains (the Krusne hory Mountains), in the western Czech Republic, thanks to its favourable morphology and climatic conditions, offers several valuable peat complexes surrounded with wet mountain spruce forests dominated by Norway spruce with a number of critically threatened species of plants and animals. The downward trend of pollutants since the nineties enabled a significant improvement of growth conditions for original tree species and ecosystems.

Dendrochronological and dendroecological studies on trees growing on peatlands in Europe are not many (BADOReK et al., 2011; CEDRO, LAMENTOWicz, 2008, 2011; HOKKA et al., 2012).

The area of the National Natural Reserve Božídarské rašeliniště peat bog includes peatland forest stands of various ages and therefore enables to study natural growth dynamics and effects of human impacts represented mostly by drainage of these stands changing its hydrological conditions.

The goal of this study was to analyze the growth development of peatland Norway spruce forests in this area in order to acquire better understanding of its dynamics and history. The specific objective was to test the null hypothesis: in forest stands older than 100 years in the moment of drainage, mean tree-ring indices of the control-site and the drained-site are equal. The assumption was that the soil drainage is expected to stimulate stem growth, including larger radial increment.

\section{Materials and methods}

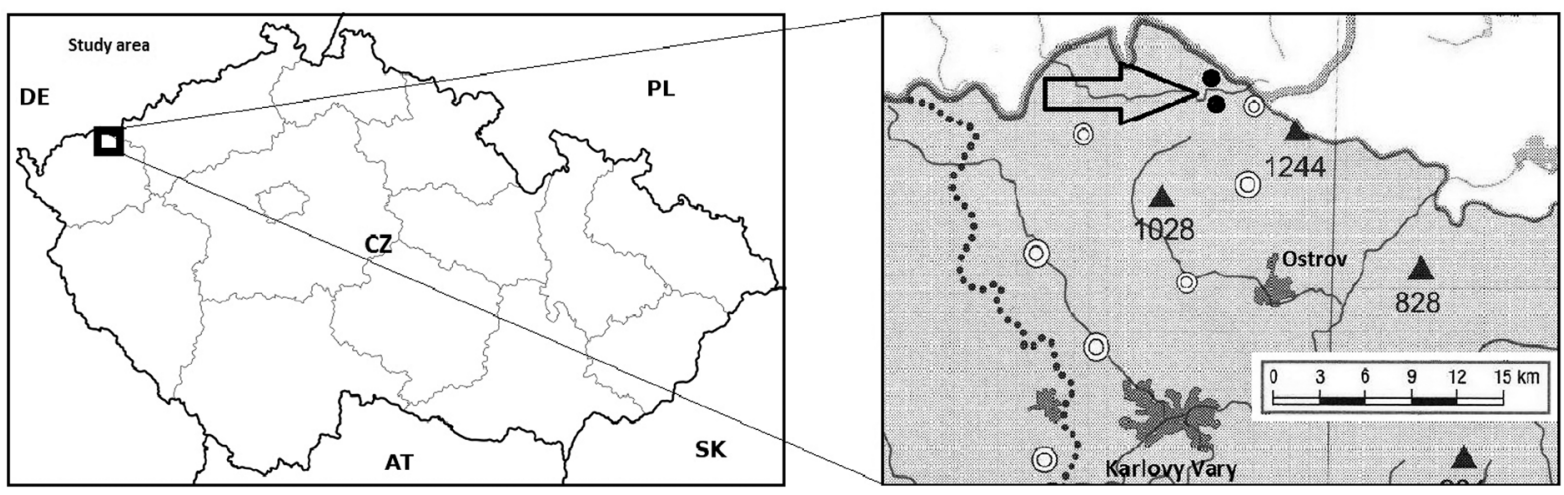

Fig. 1. Location of the study area

\subsection{Study Area}

The study was conducted in the area of the National Natural Reserve Božídarské rašeliniště peat bog in the Ore Mountains (the Krusne hory Mountains), in the western Czech Republic (Fig. 1).

For the study, based on forest management maps and aerial photographs, two stands with similar ecological conditions and age structure were selected to meet the requirements for a site homogeneity, which largely determines the quality of the chronology (COOK and KaIRIUKSTIS, 1990). Based on forest management plan, both stands are approximately 130 years old and in accordance with the Czech ecosystem classification (PLívA and PrÚŠA, 1969) classified as a Raised Bog Spruce, with an origin of slope raised bog (Dohnal, 1965) and a forest site type Sphagno-Piceetum (CHYTRÝ et al., 2001). The stands are situated on a slightly sloping terrain, trees grow on wet peat soil, irrigated only by atmospheric precipitations. Norway spruce dominates both stands and is rarely accompanied by Pinus x pseudopumilio, Betula pubescent and Sorbus aucuparia, some parts are sparsely forested. In herbal vegetation prevails Sphagnum $s p$, Vaccinium myrtilus and Eriophorum vaginatum. The average temperature is around $4^{\circ} \mathrm{C}$, average annual rainfall of $1150 \mathrm{~mm}, 110$ days long vegetation period with night frosts during whole year (Český hydrometeorologický ústav et al., 2007).

The control site (50²4'39.0'N 12 $53^{\circ} 40.3^{\prime}$ 'E), situated on a slight north-facing slope $\left(5^{\circ}\right), 993 \mathrm{~m}$ a.s.l., is located directly in the National Natural Reserve Božídarské rašeliniště peat bog and based on available forest management plans and observation on the field, it was not drained during last 50 years, likely never during the existence of the actual trees. On the other hand, the affected site $\left(50^{\circ} 25^{\prime} 08.7^{\prime \prime} \mathrm{N}\right.$ $\left.12^{\circ} 53^{\prime} 31.4^{\prime \prime} \mathrm{E}\right)$, on a slight south-facing slope $\left(2^{\circ}\right)$, $980 \mathrm{~m}$ a.s.1., is located outside the border of the National Natural Reserve. In the year 1992, the water regime of the drained site was substantially altered due to construction of numerous drainage ditches with aim to improve tree growth. 
Table 1. Basic features of the control and drained site from their forest management plans (LHProjekt 2012)

\begin{tabular}{|l|c|c|c|c|c|}
\hline \multicolumn{1}{|c|}{ Stand } & Stand age & $\begin{array}{c}\text { Mean DBH } \\
{[\mathbf{c m}]}\end{array}$ & $\begin{array}{c}\text { Mean height } \\
{[\mathbf{m}]}\end{array}$ & $\begin{array}{c}\text { Mean stem volume } \\
{\left[\mathbf{m}^{\mathbf{3}}\right]}\end{array}$ & $\begin{array}{c}\text { Number } \\
\text { of trees per ha }\end{array}$ \\
\hline Control site & 128 & 23 & 15 & 0,28 & 485 \\
\hline Drained site & 115 & 26 & 19 & 0,45 & 517 \\
\hline
\end{tabular}

\subsection{Data Sampling}

Dendrochronological analysis was performed at the turn of June-July 2012 on two 0.25 -ha square sampling plots $(50 * 50 \mathrm{~m})$. The plots were located randomly before going into the field by using GPS coordinates using aerial photographs and actual forest management plans. The each 0.25 -ha plot was divided into 25 cells $(10 * 10 \mathrm{~m})$ for systematic sampling of the trees nearest to its centre. A total of 50 samples were collected ( 25 samples from each plot). The selected trees were cored with a Pressler increment borer at breast height $(1,3 \mathrm{~m})$, one core per tree, but the direction of coring was randomly changed to balance possible irregularity in its thickness growth (ŠMELKO, 1982). A diameter of each tree at breast high (DBH) was measured. Visibly damaged and suppressed trees were avoided to reduce the variability owing to competition (COOK, KAIRIUKSTIS, 1990). However, suppressed trees are very rare given the open structure of peatland forests with trees growing at their upper climatic distribution limit. The cores were put in the straw and labelled.

\subsection{Data analysis}

In the laboratory, the increment cores were extracted from the straws, attached to the wooden holder and numbered. In total 47 undamaged cores ( 25 from the control site and 22 from the affected site) were prepared for measurement and visual analysis using the sanding method (the surface of cores was sanded with a rotary-sanding tool using a grit size 280) (CoOK and KaIRIUKSTIS, 1990). The visual analysis was made by identifying narrow marker years (YAMAGUCHI, 1991), since narrow rings are more important because these rings often record limiting environmental factors (SPEER, 2010). Annual ring widths were measured to the nearest $0,01 \mathrm{~mm}$ and cross-dated with image analysis using software WinDENDRO 2009b (RIC and Inc.) 2009). Virtual skeleton plots and graphical comparisons against a mean chronology were used to cross-date images of increment cores (MAXwell et al., 2011). The quality of data was verified with COFECHA software (HoLMES, 1983), which provides a statistical match between segments of each core and the master chronology that is made of the measurement that are entered into a program (SPEER, 2010). The data analysis and statistics was performed using software package STATISTICA 10 (StatSoft 2010). At first, the age trends from the raw chronologies were removed to obtain a raw of stationary tree-ring indices by dividing each measured ring width by its expected value (FRITTS, 1976). The expected value was calculated using the Korf's increment function (KORF, 1939). Then, the index series, separately of each sampling plot, were averaged together to form two mean-value functions of the ring indices. We used the independent two sample t-test to verify the null hypothesis that the mean treering indices of the control-site and the drained-site in the period 1985-2011 are equal. Moreover, in order to smooth out possible short-term fluctuations in our two time series in this period we used 5-year and 10-year moving average to highlight possible longer-term trend of the tree-ring indices.

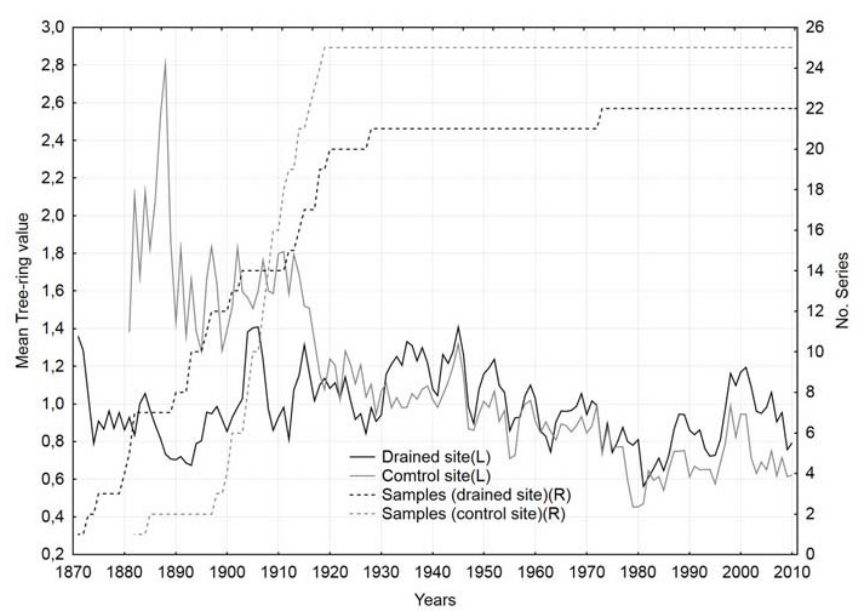

Fig. 2 (a). Chronological development (drained vs. control site) of the mean tree-ring widths and sample size (number of tree-ring series)

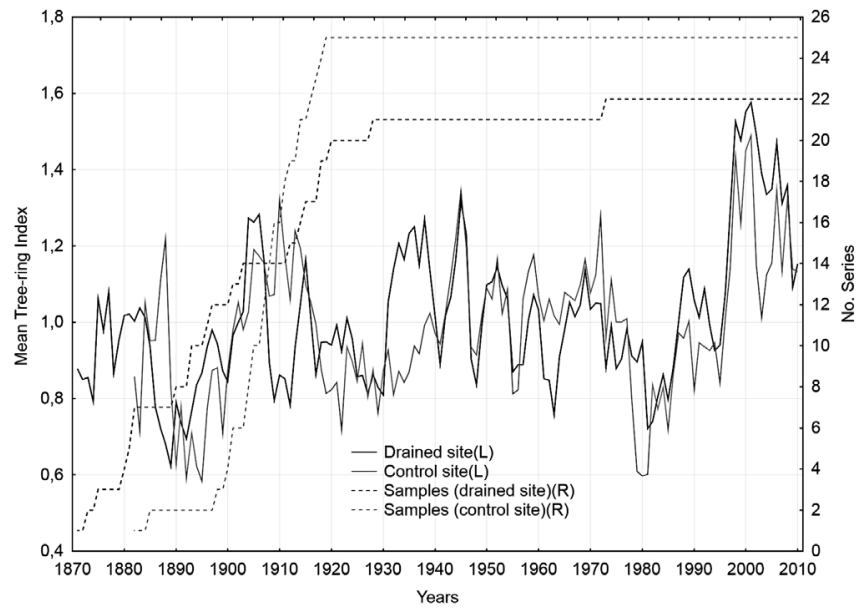

Fig. 2 (b). Chronological development (drained vs. control site) of the mean tree-ring index and sample size (number of tree-ring series) 


\section{Results}

The chronological development (drained vs. control site) of the mean tree-ring widths, the mean tree-ringindex and sample size (number of tree-ring series) on which the mean-value functions of the ring widths and indices were developed - Figure 2(a),(b), show in the period after 1940 very similar radial-growth trends. The variability of growth representing the period prior to $1940 \mathrm{can}$ be attributed to reduced sample size (the period prior to 1910). Likewise, the different variability of age structure (drained vs. control site) indicates diverse regeneration conditions on individual stands - an undergrowth origin of the drained site vs. an open-growth origin of the control site. The data analysis revealed the time span of samples, average number of treerings and its variability (Table 2).
The impact of drainage is analysed in detail of the period $1985-2011$ in Figure 3 (a), which shows the standartized mean tree-ring index (drained vs. control site) in this period. However, the radial-growth trends show in their development after the year 1992 very similar without an evident impact of drainage to the tree growth. Furthermore, we used the moving average to smooth out possible shortterm fluctuations in our two time series in this period to highlight possible longer-term trend of the tree-ring indices, as shown in Figure 3 (b): 5-year moving average and in Figure 3 (c): 10-year moving average. Likewise, with use of moving averages, there is not a sign of significant change in the tree growth on the drained site vs. the control site.

Table 2. Statistical data of the control and drained site

\begin{tabular}{|c|c|c|c|c|c|c|}
\hline Stand & Number of samples & Time span & $\begin{array}{c}\text { Average number } \\
\text { of tree-rings }\end{array}$ & $\begin{array}{c}\text { Tree age-standard } \\
\text { deviation }\end{array}$ & $\begin{array}{c}\text { Tree age-coefficient } \\
\text { of variation }\end{array}$ & Average DBH \\
\hline Control site & 25 & 130 & 108.0 & 8.3 & 0.08 & 24.34 \\
\hline Drained site & 22 & 144 & 115.3 & 20.2 & 0.18 & 26.46 \\
\hline
\end{tabular}

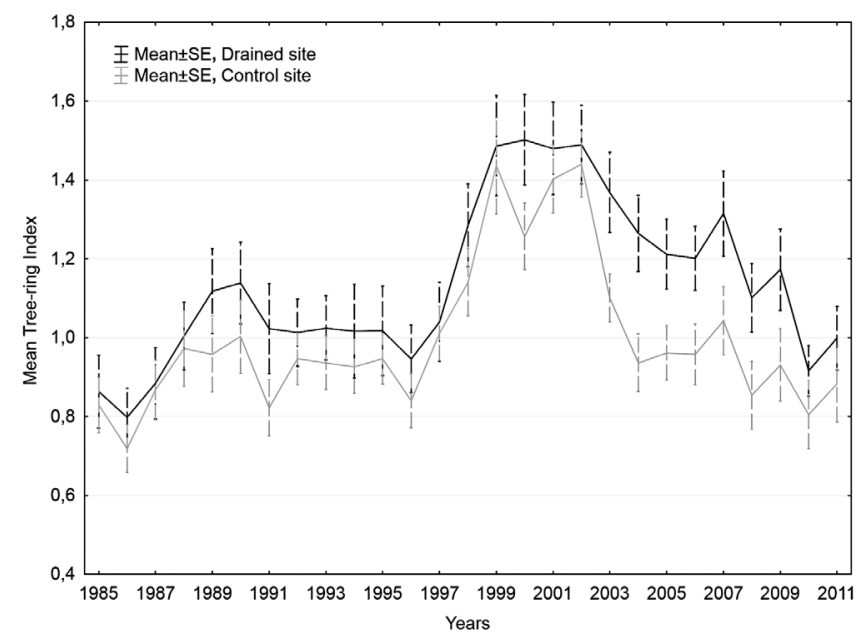

Fig. 3 (a). Standartized mean tree-ring index in detail of the period 1985-2011

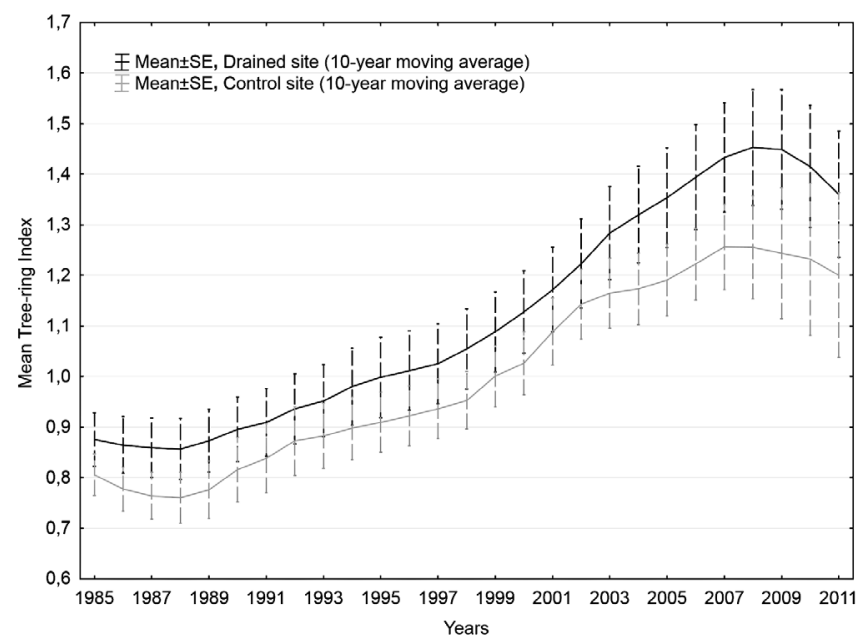

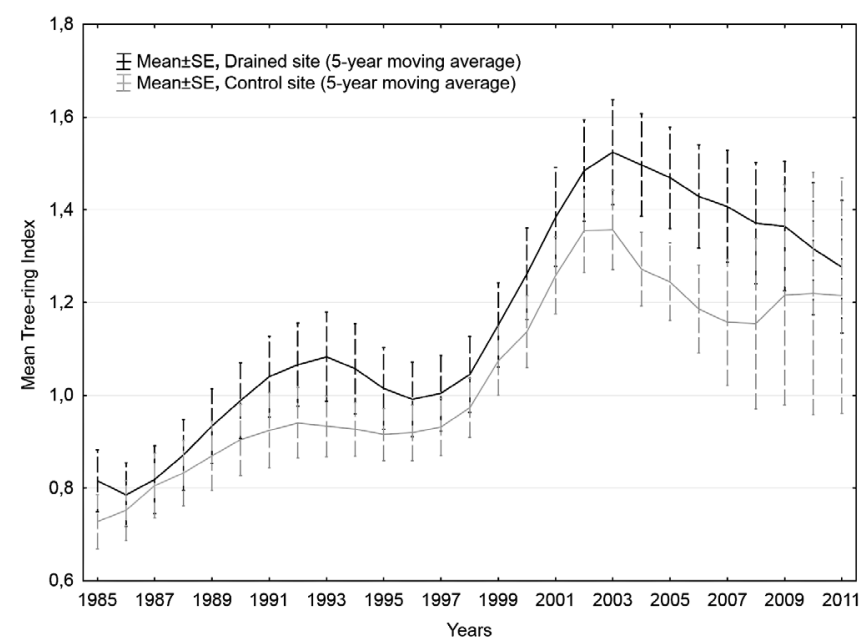

Fig. 3 (b). Standartized mean tree-ring index in detail of the period 1985-2011: 5-year moving average

Fig. 3 (c). Standartized mean tree-ring index in detail of the period 1985-2011: 10-year moving average 
Table 3. Results of independent two sample t-test in detail of the period 1985-2011 ( $\mathrm{t}-$ value, $\mathrm{p}-$ value, $\mathrm{df}=45)$

\begin{tabular}{|c|c|c|c|c|c|c|}
\hline \multicolumn{7}{|c|}{ T-test control site vs.drained site $1985-2011$} \\
\hline \multirow{2}{*}{ Years } & \multicolumn{2}{|c|}{ Individual } & \multicolumn{2}{|c|}{ 5-year moving average } & \multicolumn{2}{|c|}{10 -year moving average } \\
\hline & t-value & $\mathbf{p}$ & t-value & $\mathbf{p}$ & t-value & $\mathbf{p}$ \\
\hline 1985 & 0.295 & 0.769 & 0.997 & 0.324 & 0.884 & 0.381 \\
\hline 1986 & 0.827 & 0.413 & 0.357 & 0.723 & 1.137 & 0.262 \\
\hline 1987 & 0.141 & 0.888 & 0.128 & 0.898 & 1.211 & 0.232 \\
\hline 1988 & 0.251 & 0.803 & 0.374 & 0.710 & 1.240 & 0.221 \\
\hline 1989 & 1.111 & 0.272 & 0.588 & 0.560 & 1.188 & 0.241 \\
\hline 1990 & 0.980 & 0.332 & 0.755 & 0.454 & 0.938 & 0.353 \\
\hline 1991 & 1.894 & 0.065 & 0.978 & 0.333 & 0.766 & 0.448 \\
\hline 1992 & 0.622 & 0.537 & 1.082 & 0.285 & 0.701 & 0.487 \\
\hline 1993 & 1.177 & 0.245 & 1.316 & 0.195 & 0.953 & 0.346 \\
\hline 1994 & 0.531 & 0.598 & 1.185 & 0.242 & 0.984 & 0.330 \\
\hline 1995 & -0.203 & 0.840 & 0.972 & 0.336 & 0.952 & 0.346 \\
\hline 1996 & 0.929 & 0.358 & 0.734 & 0.467 & 0.976 & 0.334 \\
\hline 1997 & 0.533 & 0.597 & 0.716 & 0.478 & 1.024 & 0.311 \\
\hline 1998 & 1.133 & 0.263 & 0.702 & 0.486 & 1.157 & 0.253 \\
\hline 1999 & 0.499 & 0.620 & 0.663 & 0.511 & 1.056 & 0.297 \\
\hline 2000 & 1.531 & 0.133 & 1.004 & 0.321 & 1.114 & 0.271 \\
\hline 2001 & 0.634 & 0.530 & 0.935 & 0.355 & 0.939 & 0.352 \\
\hline 2002 & 0.609 & 0.546 & 0.928 & 0.359 & 0.920 & 0.363 \\
\hline 2003 & 2.387 & 0.021 & 1.203 & 0.235 & 1.068 & 0.291 \\
\hline 2004 & 2.369 & 0.022 & 1.686 & 0.099 & 1.296 & 0.202 \\
\hline 2005 & 1.176 & 0.246 & 1.648 & 0.106 & 1.455 & 0.153 \\
\hline 2006 & 0.854 & 0.398 & 1.667 & 0.102 & 1.489 & 0.144 \\
\hline 2007 & 0.350 & 0.728 & 1.358 & 0.181 & 1.403 & 0.167 \\
\hline 2008 & 0.537 & 0.594 & 0.938 & 0.353 & 1.259 & 0.214 \\
\hline 2009 & 0.095 & 0.925 & 0.521 & 0.605 & 1.058 & 0.296 \\
\hline 2010 & -0.162 & 0.872 & 0.313 & 0.756 & 0.815 & 0.419 \\
\hline 2011 & 0.098 & 0.922 & 0.206 & 0.838 & 0.728 & 0.471 \\
\hline
\end{tabular}

The result of the independent two sample t-test for the period of 1985-2011 has not revealed any substantial statistically important difference in the mean index between the control site and drained site (Table 3).

\section{Discussion}

Our results not revealed any statistically important difference in tree growth between the unaffected control site and drained site after the year 1992. In naturally forested peatlands and wetlands, tree growth is generally dependent on hydrological variations because the high water table level significantly limits tree growth (MACDONALD, YIN, 1999). Thus, drainage of peatlands for forestry purposes aims at removing the restrictive role of naturally high water table levels on tree growth (HoKKA et al., 2012). Alteration of the hydrological regime causes lowered groundwater levels, shifts between evapotranspiration and evaporation and gradual changes, such as an expanded root zone, increased interception, etc. (IRITZ et al., 1994). In one study of tenth-year growth and yield improvements of black spruce in a forested Ontario peatland, the Wally Creek area, a response to drainage took about five to seven years (McLAREN, JEGLum, 1998). Even though hydrological conditions of our drained site had been significantly altered, this fact did not enhanced tree growth in following 7-years period compared to the control site.

One important limiting factor might be the age of a forest stand at the time of drainage. Some older studies carried out in the former USSR by PiawCZENKo, SABo, 1962 (SochA, 2012) indicated, that Norway spruce may still respond to drainage at ages over 100 years. In the study of growth of black spruce, a response occurred primarily in trees that were young to middle-aged at the time of drainage (MaCDonald, YIn, 1999). In case of Scots pine, it was found that the asymptote for height growth is a function of stand age and the timing of drainage (HoKKA, OJANsuU, 2004). Based on one study focused on a long-term effect of wetland drainage on the productivity of Scots pine in Poland, the effect of drainage depended primarily on the age of the stand at the time of drainage; a positive growth response (i.e., an increase in height) was observed in stands that were younger than 45-50 years at the time of drainage; stands older than 50 years at the time of drainage were assumed to be unaffected (Socha, 2012). In our study, the affected site was drained in the year 1992, at the time when the average age of the stand, based on the collected samples, reached 105-110 years. This average age is in line with the age stated in related forest management plan, which indicates 
the average age of 110 years. The result of our study has not revealed the ability of Norway spruce to respond to drainage at ages over 100 years.

Another important limiting factor might be the fact, that the response of trees to drainage is influenced with a capability of a tree to utilize deeper soil layers with its root system (SCHWEINGRUber, 2007). From the comparison of Norway spruces growing on the well-drained and poorly drained sites resulted, that the root systems were two times shallower in poorly drained sites than in well-drained ones and the horizontal development of root biomass was detrimental to roots penetrating vertically (root systems in these sites were broader by one-third units than those in well-drained sites) (KoNôPKA, 2002). Likewise, trees grown on wet sites need larger root systems for oxygen and nutrient uptake (ToBin et al., 2007) and have larger belowground biomass expressed on stem diameter at waterlogged than well-drained soils (KoNôPKA et al., 2010). Thus, drainage of soil is assumed to stimulate stem increment owing to increased ration for carbohydrates allocation between stem and root system. However, the weak reaction of threes to soil drainage in our study could be limited with the fact, that in the average age of 105-110 years, trees were not already able to adapt their root systems to modified water table level.

At both sites, there is evident a significant growth reduction between the years $1970-1980$ as well as the following recovery of growth and the rapid increase of the mean radial increment, which might be attributed to the increase and following significant reduction of $\mathrm{SO}_{2}$ emission and climate change. A recent study of silver fir (Abies alba Mill.) in Southern Germany provided clear evidence that $\mathrm{SO}_{2}$-immissions play a key role in such decline and that tree growth corresponds with the regional and temporal pattern of $\mathrm{SO}_{2}$ pollution (ElLING et al., 2009). In another study in Harz Mountains in Germany, $\mathrm{SO}_{2}$ pollution caused reduced tree-ring width in Norway spruce (Picea abies L. Karst.) and a rapid recovery of stem growth after the reduction of $\mathrm{SO}_{2}$ emission (HAUCK et al., 2012). The recent climate-growth relationships of silver fir (Abies alba Mill.) was investigated in the Western Carpathians in Slovakia as well (BošELA et al., 2014). The results of this study provide clear evidence of significant increase of silver fir's radial increment over the entire Western Carpathian area since $1970-1980$ and the assumption that the most probable factors behind the rapid recovery of tree radial increment were reductions in emissions of $\mathrm{NO}_{3}$ and $\mathrm{SO}_{2}$, alongside a significant increase in mean June, July and April temperatures.

The data analysis in our study further indicated, that trees situated on the drained site have obviously a higher average annual radial increment during their existence. Due to the fact, that even very small differences in the site condition influence growth (SCHWEINGRUBER, 2007), we can attribute this variance to a slightly different terrain conditions and stand exposure: while the control site has the northern exposure, the drained site benefits from its southern exposure. Moreover, the area of the drained site was historically under stronger anthropogenic influence, hence we estimate other interventions in its hydrological conditions somewhere around 1930, in spite of exact historical records are not available. Thus, the drained site might benefit over a long period from lower water table level. Generally, it is possible to assume that young to middle-aged trees respond better to drainage and build a deeper root system, which is an advantage in the period of drought like in the year 2003 (Meteorological Station Fichtelberg, Deutscher Wetterdienst), when the recent differences between the mean tree-ring width started.

\section{Conclusions}

The mean-value functions of the ring indices, comparing the affected site with the control site, showed in the period after 1940 very similar radial-growth trends. In the year 1992, the water regime of the drained site was substantially altered due to construction of numerous drainage ditches with aim to improve tree growth. However, the radial-growth trends show in their development after the year 1992 very similar radial-growth trends without an evident impact of drainage to the tree growth. In order to smooth out possible short-term fluctuations, we used 5-year and 10 -year moving average to highlight possible longer-term trend of the tree-ring indices. Likewise, there is not a sign of significant change in the tree growth on the drained site vs. the control site. The result of the independent two sample t-test has not revealed any substantial statistically important difference in the mean index between the control site and drained site.

The obtained results are a source of further information in order to understand better the growth dynamics of peatland Norway spruce forests to be able to manage effectively its protection. At the same time, the study shows, that human intervention in such ecosystems should be beforehand carefully analyzed from different point of views, because not always bear expected results. In further study at the field the following effect to be analysed: the impact of drainage response in trees young to middle-aged at the time of drainage; the effects of soil drainage to tree stability and health status; influence of climate variables and air pollutants to the growth of trees.

\section{References}

Badorek, T., E.S. Tuittila, P. Ojanen and Minkkinen, K., 2011: Forest floor photosynthesis and respiration in a drained peatland forest in southern Finland. Plant Ecology \& Diversity, 4(2-3): 227-241. 
Bošela, M., Petráš, R., Sitková, Z., Priwitzer, T., Pajtík, J., Hlavatá, H., Sedmák, R. and Tobin, B., 2014: Possible causes of the recent rapid increase in the radial increment of silver fir in the Western Carpathians Environmental Pollution, 184: 211-221.

Cedro, A., Lamentowicz, M., 2008: The last hundred years' dendroecology of Scots pine (Pinus sylvestris L.) on a Baltic bog in Northern Poland: Human impact and hydrological changes. Baltic Forestry, 14(1): 26-33.

Cedro, A., Lamentowicz, M., 2011. Contrasting responses to environmental changes by pine (Pinus sylvestris L.) growing on peat and mineral soil: An example from a Polish Baltic bog. Dendrochronologia, 29(4): 211-217.

Chytrý, M., KuČERA, T. and KoČí, M., 2001: Katalog biotopů České republiky. Agentura ochrany prŕírody a krajiny ČR, Praha.

CoOK, E.R., Kairiukstis, L.A., 1990: Methods of Dendrochronology. International Institute for Applied Systems Analysis.

Český hydrometeorologický ústav, Univerzita Palackého, Národní klimatický program České republiky, and Česko. Ministerstvo životního prostředí. 2007. Atlas podnebí Česka Climate atlas of Czechia. Praha, Český hydrometeorologický ústav, CD-ROM.

Dohnal, Z., 1965: Československá rašeliniště a slatiniště. Československá akademie věd, Praha.

Elling, W., Dittmar, C., Pfaffelmoser, K. and Rotzer, T. 2009: Dendroecological assessment of the complex causes of decline and recovery of the growth of silver fir (Abies alba Mill.) in Southern Germany. Forest Ecology and Management, 257(4):1175-1187.

FritTs, H.C., 1976: Tree Rings and Climate. Academic Press, New York.

Gustavsen, H.G., Heinonen, R., Paavilainen, E. and ReinikaiNEN, A., 1998: Growth and yield models for forest stands on drained peatland sites in southern Finland. Forest Ecology and Management, 107(1-3):1-17.

Hauck, M., Zimmermann, J., Jacob, M., Dulamsuren, C., Bade, C., Ahrends, B. and Leuschner, C., 2012: Rapid recovery of stem increment in Norway spruce at reduced $\mathrm{SO}_{2}$ levels in the Harz Mountains, Germany. Environmental Pollution, 164:132-141.

HokKa, H., OjansuU, R., 2004: Height development of Scots pine on peatlands: describing change in site productivity with a site index model. Canadian Journal of Forest Research / Revue Canadienne De Recherche Forestière, 34(5):1081-1092.

Hokka, H., Salminen, H. and Ahti, E., 2012: Effect of temperature and precipitation on the annual diameter growth of Scots pine on drained peatlands and adjacent mineral soil sites in Finland. Dendrochronologia, 30(2):157-165.

Holmes, R.L., 1983: Computer-assisted quality control in tree-ring dating and measurements. Tree-Ring Bull., 44:69-75.

IRITZ, L., JOHANSSON, B. and LunDIN, L., 1994: Impacts of forest drainage on floods. Hydrological Sciences Journal, 39(6): 637-661.
KonôPKA, B., 2002: Relationship between parameters of the aboveground parts and root system in norway spruce with respect to soil drainage. Ekológia-Bratislava, 21(2): 155-165.

KonôPKa, B., Moravčík, M., PAjtík, J. and Lukac, M., 2010: Effect of soil waterlogging on below-ground biomass allometric relations in Norway spruce. Plant Biosystems, 144(2): 448-457.

KoRF, V., 1939: Př́ispěvek k matematické formulaci vzrůstového zákona lesních porostů. Lesnická práce, 18: 339-379.

LiefFers, V.J., RothwelL, R.L., 1987: Effects of drainage on substrate-temperature and phenology of some trees and shrubs in an alberta peatland. Canadian Journal of Forest Research / Revue Canadienne De Recherche Forestière, 17(2): 97-104.

MacdOnAld, S.E., Yin, F.Y., 1999: Factors influencing size inequality in peatland black spruce and tamarack: evidence from post-drainage release growth. Journal of Ecology, 87(3): 404-412.

Marttila, H., Klove, B., 2010: Dynamics of erosion and suspended sediment transport from drained peatland forestry. Journal of Hydrology, 388(3-4): 414-425.

Marttila, H., Vuori, K.M., Hokka, H., Jamsen, J. and Klove, B., 2010: Framework for designing and applying peak runoff control structures for peatland forestry conditions. Forest Ecology and Management, 260(8): 1262-1273.

Maxwell, R.S., Wixom, J.A. and Hessl, A.E., 2011: A comparison of two techniques for measuring and crossdating tree rings. Dendrochronologia, 29(4): 237-243.

McLaren, B.E., Jeglum, J.K., 1998: Black spruce growth and foliar nutrient responses to drainage and fertilization: Wally Creek, Ontario. Forestry Chronicle, 74(1): 106-115.

Moilanen, M., Hytonen, J. and Leppala, M., 2012: Application of wood ash accelerates soil respiration and tree growth on drained peatland. European Journal of Soil Science, 63(4): 467-475.

Paavilainen, E., PÄIvänen, J., 1995: Peatland Forestry: Ecology and Principles. Springer-Verlag Berlin Heidelberg, Germany.

Plíva, K., PrưŠA, E., 1969: Typologické podklady pěstování lesů. Praha, SZN.

Prévost, M., Plamondon, A.P., Belleau, P., 1999: Effects of drainage of a forested peatland on water quality and quantity. Journal of Hydrology, 214(1-4): 130-143.

Rottmann, M., 1989: Wind- und Sturmschäden im Wald. J.D. Sauerländers Verlag.

Schweingruber, F.H., 2007: Wood Structure and Environment. Springer-Verlag Berlin Heidelberg, 279 p.

Socha, J., 2012: Long-term effect of wetland drainage on the productivity of Scots pine stands in Poland. Forest Ecology and Management, 274: 172-180.

SPEER, J.H., 2010: Fundamentals of tree-ring research. The University of Arizona Press, Arizona, USA.

ŠMelKo, Š., 1982: Biometrické zákonitosti rastu a prírastku lesných stromov a porastov. Príroda, Bratislava, 184 p. 
Tobin, B., J. Cermak, D., Chiatante, F., Danjon, A., Di Iorio, Dupuy, L., Eshel, A., Jourdan, C., Kalliokoski, T., Laiho, R., Nadezhdina, N., Nicoll, B., Pages, L., Silva, J. and SpaNOS, I., 2007: Towards developmental modelling of tree root systems. Plant Biosystems, 141(3): 481-501.

YAMAGUCHI, D.K., 1991: A Simple method for cross-dating increment cores from living trees. Canadian Journal of Forest Research / Revue Canadienne de Recherche Forestière, 21(3): 414-416.

\section{Souhrn}

Rašelinné smrčiny představují velmi cenné ekosystémy se značným významem pro ochranu přírody. Protože není doposud $\mathrm{k}$ dispozici mnoho dendroekologických studií růstových charakteristik smrku ztepilého (Picea abies L. Karst.) na rašelinných stanovištích střední Evropy, byl v oblasti Krušných hor v západní části ČR (obr. 1) proveden dendrochronologický průzkum, porovnávající vliv odvodnění stanoviště ve věku porostu přesahujícím 100 let na radiální př́írůst kmene smrku ztepilého. V oblasti NPR Božídarské rašeliniště byly odebrány vývrty ze čtvercových výzkumných ploch $(50 * 50 \mathrm{~m})$ z porostu odvodněného v roce 1992 ("drained site") a kontrolního stanoviště ("control site") - základní charakteristiky porostů uvádí tabulka 1 . Z každé plochy bylo odebráno 25 vývrtů ve výšce
1,3 m, z každého stromu po 1 vývrtu a změřena výčetní tloušt'ka vzorníku. Nepoškozené vývrty byly změřeny a datovány v softwaru WinDENDRO 2009b (RIC and Inc.) 2009), kvalita dat ověřena v software COFECHA (HoLmEs, 1983). Statistická data odebraných vývrtů uvádí tabulka 2. Standartizace byla provedena za použití Korfovy př́růstové funkce (KoRF, 1939) v software STATISTICA10 (StatSoft 2010). Byly vytvořeny řady průměrných šířek letokruhů a statisticky porovnány průměrné hodnoty letokruhových indexů. Vývoj časové řady průměrných šířek letokruhů (obr. 2 a) a letokruhových indexů (obr. 2 b) je po roce 1940 velmi podobný. Rozdílný trend př́růstů před rokem 1940 je značně ovlivněn sníženým počtem vzorků (viz obr. 2 a,b “No. Series”), zejména před rokem 1910. Vliv odvodnění je detailně analyzován za období 1985-2011 (obr. 3a) a porovnává vývoj průměrného letokruhového indexu (odvodněná vs. neodvodněná lokalita) v tomto období. Časová řada průměrných letokruhových indexů po roce 1992 má velmi obdobný trend, bez evidentního vlivu odvodnění na radiální př́růsst. Použití 5-ti a 10-ti letých klouzavých průměrů k eliminaci krátkodobých výkyvů časové řady tento stejný trend ještě více zdůraznilo (obr. 3 b,c). Výsledky dvouvýběrového t-testu pro období 1985-2011 neodhalily podstatný statisticky významný rozdíl v hodnotách průměrného letokruhového indexu (tab. 3), což naznačuje velmi slabou odezvu radiálního př́růstu starších stromů na odvodnění stanoviště. 